\title{
TABULAR ICEBERGS: IMPLICATION FROM GEOPHYSICAL STUDIES OF ICE SHELVES*
}

\section{(Abstract only)}

\author{
by
}

Sion Shabtaie and Charles R. Bentley

(Geophysical and Polar Research Center, Department of Geology and Geophysics, University of Wisconsin-Madison, Madison, WI 53706, U.S.A.)

\section{ABSTRACT}

Recent geophysical and glaciological investigations of the Ross Ice Shelf have revealed many complexities in the ice shelf that can be important factors in iceberg structure. The presence of rift zones, surface and bottom crevasses, corrugations, ridges and troughs, and other features could substantially modify the hydraulics of iceberg towing and lead to disintegration of the berg in the course of transport.

The relationships between the elevation above sea-level and total ice thickness for three ice shelves (Ross, Brunt, and McMurdo) are given; from them, expressions for the thickness/ freeboard ratios of tabular icebergs calved from these ice shelves are obtained. The relationships obtained from the measured values of surface elevation and ice thickness are in agreement with models derived assuming hydrostatic equilibrium.

Areas of brine infiltration into the Ross Ice Shelf have been mapped. Examples of radar profiles in these zones are shown. Absorption from the brine layers results in a poor or absent bottom echo. It is probable that little saline ice exists at the bottom of the Ross Ice Shelf front due to a rapid bottom melting near the ice front, and that the thickness of the saline ice at the bottom of icebergs calving from the Ross Ice Shelf is no more than a few meters, if there is any at all.

We have observed many rift zones on the ice shelf by airborne radar techniques, and at one site the bottom and surface topographies of (buried) rift zones have been delineated. These rift zones play an obvious role in iceberg formation and may also affect the dynamics of iceberg transport. Bottom crevasses with different shapes, sizes, and spacings are abundant in ice shelves; probably some are filled with saline ice and others with unfrozen sea-water. Existence of these bottom crevasses could lead to a rapid disintegration of icebergs in the course of transport, as well as increasing the frictional drag at the ice-water boundary.

Radar profiles of the ice-shelf barrier at four sites in flow bands of very different characteristics are shown. In some places rifting upstream from the barrier shows regular spacings, suggesting a periodic calving. Differential bottom melting near the barrier causes the icebergs to have an uneven surface and bottom (i.e. dome-shaped).

Electrical resistivity soundings on the ice shelf can be applied to estimate the temperaturedepth function, and from that the basal massbalance rate. With some modifications, the technique may also be applied to estimating the basal mass-balance rates of tabular icebergs. 